\title{
ANALYSIS OF SURVEY RESULTS IN TERMS OF SELECTION OF CHARACTERISTICS OF THE MINING RESCUER TO THE RANKS OF RAPID RESPONSE
}

\author{
Aneta GRODZICKA, Jan SZLAZZAK \\ Silesian University of Technology
}

\begin{abstract}
:
The authors of the current study undertook the subject of the analysis features of the mining rescuer as a member of the ranks of the rescue, with particular emphasis on the following parameters: heart rate, body weight, height, BMI, age and seniority in the mining and rescue. This publication concerns the analysis of the test results of these characteristics rescuer as a potential member of the ranks of the rescue, taking into account its risk appetite, stress resistance, attitude towards life, the role of the team, teamwork, attitude to work, motivation to work and physical fitness.
\end{abstract}

Key words: mining, search and rescue, The questionnaire

\section{INTRODUCTION}

The basic principles of the Act defines the mining Geological and Mining Law [23], which contains the general principles of the organization of mine rescue, and the specific rules included in the Regulation on the mine rescue [24].

For the purposes of implementation issues analysis undertaken characteristics of the mining rescuer as a member of the ranks of the rescue are essential among others two following regulations:

1. The mine rescue carried out specialized examinations, specialized psychological testing and specialized training. Research and training organized and conducted by the operator of the mine rescue or entrepreneur that meets the requirements for entities professionally engaged in mine rescue [23].

2. Lifeguard mining can be a person who: 21 years of age; He worked at least 12 months in the mining plant in the specialty; It has an appropriate health and adequate psychological predispositions, confirmed by specialized research; He completed the basic course for candidates for mine rescuers and passed the examination with a positive result; the Polish language in speech and writing, to the extent necessary for the exercise of mining activities rescuer [24].

Summing up the analysis of the legal basis it can be stated that the current mining regulations specify the following characteristics of the mining rescuer:

- age and experience: minimum age of 21 years and a minimum work experience in the mining industry, at least 12 months in the mining plant in the specialty,

- qualifications: appropriate theoretical knowledge and relevant practical skills, including completed the basic course and periodic courses, participation in readiness specialist, participation in exercises and rescue operations,
- psychophysical efficiency: adequate health, confirmed by specialized medical examination and appropriate psychological predispositions, confirmed by specialized psychological tests.

Currently not identified in the literature of mining as a separate issue cognitive problems analysis of characteristics of the mining rescuer as a member of the ranks of the rescue.

Monographs on. Mine rescue, besides described above qualification requirements, focusing attention primarily on the organization and technique of mine rescue, for example $[5,21]$ and safety management in the rescue, for example [11].

Publications in the field of underground mining generally concern the analysis of working conditions underground and more detailed research purposes, among others:

- analysis of energy expenditure mine rescuers, for example [6],

- analysis of adaptation mine rescuers to the heat load, for example[12]

- analysis safe transition time rescue teams, for example [4],

- analysis of human physiological parameters in terms of climatic hazard in underground mines, for example [2],

- analysis organization exercises in mine rescue using fire simulation in underground mines, for example [3],

- analysis of physiological parameters and professional experience of mine rescuers in terms of the minimum transit time rescue teams, for example $[15,16,17$, $18,19,20]$.

A related issues is the analysis of risky behavior of employees in the coal mining industry, which is taken during the implementation of a more general research purposes, 
among which are, among others. The following problem areas:

- system management of work safety in the mining industry, for example[13],

- safety culture mining crews, for example [7, 9, 10],

- formation of safe behaviors miners, for example $[8,22]$,

- risk rescue operations in mines, for example [1, 14].

Since 2012 there have been many studies on a group of mine rescuers and professional rescuers, as well as officers and directors of Regional Mine Rescue Station. The research was carried out through surveys, interviews and research rescue exercise in the chamber. Rescuers in the group were selected based on their personal characteristics such as height, weight, BMI and taking into account their seniority and age. Then measured the time they move in excavations in the chamber exercise. Rescuers undergo tests have created conditions similar to the conditions in the mine, thanks to the modernized chamber located at the Regional Mine Rescue Station in Bytom.

The studies lasted more than two years, and the results of the different stages of the study were successively published in the News of Mining. The literature review was presented in a series of articles [15, 16, 17, 18, 19, 20].

As stated above tests were carried out in the chamber exercises at the Regional Mine Rescue Station in Bytom. Research have joined the two hosts on some exercises with randomly selected coal mines. At the very beginning, the presence of the reported research lifeguards, then they were registered in the system, which has allocated an individual number to each of them.

Data on age, years of work in the mining and rescue, and weight were collected immediately after registration rescuer in the system. At the end of rescuers assumed locator on hand and meter to measure heart rate assumed chest. The person supervising the test at any time had a preview so where there is a lifeguard. Furthermore, it was also possible to monitor continuously the heart pulse rate. Rescuers were subjected to stress tests, then for 30 minutes were in the excavations at elevated temperatures and then launched an exercise on the passage through the smoky pit with a length of $50 \mathrm{~m}$ and the excavation of $80 \mathrm{~m}$ with good visibility. The time passing of each of the pits.

After analyzing the obtained results in the selection of rescuers host according to their similar personal characteristics and create a so-called.: "Host rapid response." Host would consist of rescuers receiving the best results in exercises. The current composition of the ranks is determined by the Head of the Mine Rescue Station and rescuers in the composition of the work and practice.

On the other hand, there are situations where dangerous time can play an important - favorable or unfavorable - role in the whole course of the rescue operation. Then to penetrate pits and quickly reaching the scene of the incident, the head of the rescue operation could use just such a patrol.

The studies involved a total of 36 hosts, and special attention is paid to the time of their passing in the chamber designated exercise excavations. For this analysis assumed the best of times.

\section{RESEARCH RESCUERS IN THE CHAMBER EXERCISES}

After studies the results classified in terms of:

- Index BMI - the fastest host received a transition time 15 minutes and had a team of 4 rescuers and degree of obesity and one of the second degree (according to $\mathrm{BMI}$ ). The value of heart rate rescue team immediately prior to exercise ranged from 82 to 90 .

Rescuers from the patrol had a weight of 84.6 to $103,7 \mathrm{~kg}$ and age from 40 to 44 years:

- age rescuers - a host that has passed the pit during the 19 minutes he had in his composition rescuer youngest aged 35 and the oldest 48 years old. Total work experience in the mining industry throughout the ranks was 100 years, and in mine rescue 70.5 years. The average increase lifeguard at the host was $172.2 \mathrm{~cm}$, and the average value of heart rate immediately before the exercise was 80.2 . Rescuers weight ranged from 80.0 to $102.4 \mathrm{~kg}$.

- growth rescuers - rescuers who defeated the pits 17 minutes characterized with an average age of 35.4 years, the average work experience in mining 12 years and the average seniority in mine rescue 5.6 years. Growth housed the range of 176 to $186 \mathrm{~cm}$. In terms of growth was fairly balanced host. The total average weight of rescuers was $88.36 \mathrm{~kg}$.

- classification according to the heart rate immediately before the exercise clearly showed that the rescuers with a lower average value of heart rate achieved shorter transition time. Fastest host reached the time 17 minutes. Rescuers have the ranks of from 28 to 45 years work experience in the mining industry 5-25 years and an internship in the mine rescue $1-11$ years. The average value of heart rate in these rescuers immediately before the exercise was 80 .

According to these four classifications to the ranks of rapid response should choose those rescuers who during the exercise achieved the best results.

It should be noted that in the study participated 36 hosts (each host the 5 rescuers) with different personality traits. The research material was so extensive. The best transition time was 15 minutes, and the worst 28 minutes. The difference between the fastest and slowest host was so 13 minutes, ie. Approx. 86\%.

One would assume that the host of the first to reach the scene almost two times faster than the slowest host.

If you would need to create the ranks of rapid response on the basis of the study it can be concluded that it should consist of the rescuers have the best from among the following $[15,16,17,18,19,20]$ :

- rescuers older defeated faster smoky pit, in which they had to demonstrate experience acquired during operation.

In such a situation it can be argued that passing of time determined by experience lifeguards.

- experience rescuers was analyzed by seniority in mine rescue, work experience in the mining industry, participation in rescue and preventive work carried out by the mines,

- rescuers should be characterized by BMI outside the obesity or I degree of obesity,

- rescuers before the job are low (80-90), the prevalence of heart received a shorter transition time.

Finally - the selection of lifeguards to rescue teams, and in particular to the ranks of rapid response should be taken into account also their mental aptitude and the experience gained so far conducted actions [15]. 
The composition of rescue teams is determined in such a way that the host were rescuers with different professional specialties.

To the ranks of the chosen people with varying degrees of experience - so that the rescuer with less experience can learn from the older rescuers who already have large work experience.

When selecting responders should pay attention to their tendency to risky behavior. Occupation rescuer mining is difficult and affects his psyche.

Each rescuer should possess the qualities of a moderately risky behavior because this occupation can be classified as extreme due to the nature and the conditions in which rescuers are working.

Host rescue should not only consist of people who prefer a risk, even a moderate.

The rescue operation is needed courage and above all prudence.

This problem explaining described later in this article surveys.

\section{SURVEYS}

In order to determine the profile silhouette of a lifeguard conducted an anonymous survey, which was attended by paramedics randomly selected mining coal mine.

The sample was consisted of $25 \%$ of the registration status of rescuers. The questionnaire was carried out during the theoretical part during exercises in the Regional Mine Rescue Station.

Rescuers were informed about the purpose of the study and publication of the results.

The questionnaire was conducted anonymously. The duration of filling in questionnaires was 20 minutes. Rescuers have clearly defined how to fill in the questionnaire.

Survey profiles lifeguard mining as a member of the ranks of the rescue consisted of 16 questions, which consist of 3 or 5 response. Questions included in the survey were to emerge the essential features of a lifeguard, which he wanted to work lifeguard respondent.

At the end of the survey respondents completed a metric to determine their age and seniority.

Throughout the research group participated 102 rescuers, where $57.3 \%$ of them prefer to work with someone who shows no inclination to risk or risk aversion. However, from the belayer I would like to work $20.4 \%$ (Table 1).

Table 1

The results answer to question 1

\begin{tabular}{lcc}
\hline \multicolumn{1}{c}{ Willingness to take risks } & \multicolumn{2}{c}{ Sum } \\
\cline { 2 - 3 } & number & $\%$ \\
a. Belayer & 21 & 20.4 \\
b. Dangeresque & 23 & 22.3 \\
c. A person does not show risk appetite & 59 & 57.3 \\
or risk aversion & & \\
\hline
\end{tabular}

Table 2

The results answer to question 2

\begin{tabular}{lcc}
\hline \multicolumn{1}{c}{ Resistant to stress } & \multicolumn{2}{c}{ Sum } \\
\cline { 2 - 3 } & number & $\%$ \\
a. Stoik & 18 & 17.5 \\
b. Choleric & 11 & 10.7 \\
$\begin{array}{l}\text { c. A person does not show an in- } \\
\text { creased nervousness or indifference }\end{array}$ & 74 & 71.8 \\
\hline
\end{tabular}

Table 2 contains the results where analyzed was resistant to stress by choosing the person with whom the respondent wants to work. $71.8 \%$ indicated the person is not showing an increased nervousness or indifference. While $17.5 \%$ chose stoic.

Outlook on life shown in Table 3, which would work with the optimistic $69.9 \%$. Only $4.9 \%$ would choose to work with a pessimist. While $25.2 \%$ chose the answer the person does not pose an increased self-confidence or self-doubt (Table 3).

Table 3

The results answer to question 3

\begin{tabular}{lcc}
\hline \multicolumn{1}{c}{ Willingness to take risks } & \multicolumn{2}{c}{ Sum } \\
\cline { 2 - 3 } & number & $\%$ \\
a. Optimist & 72 & 69.9 \\
b. Pessimist & 5 & 4.9 \\
$\begin{array}{l}\text { c. A person does not show an in- } \\
\text { creased self-confidence or self-doubt }\end{array}$ & 26 & 25.2 \\
\hline
\end{tabular}

Table 4 contains answers about the role in the team, where the person who is a leader and collaborator, depending on the needs of a colleague would like to work $36.9 \%$. Only $3.9 \%$ chose the leader as a person working with him in the host.

Table 4

The results answer to question 4

\begin{tabular}{lcc}
\hline \multicolumn{1}{c}{ Role In the team } & \multicolumn{2}{c}{ Sum } \\
\cline { 2 - 3 } & number & $\%$ \\
a. Leader & 4 & 3,9 \\
b. Associate & 38 & 36.9 \\
c. A person who is a leader and collab- & 61 & 59.2 \\
orator depending on your needs & & \\
\hline
\end{tabular}

Table 5 contains the results of cooperation in the team. The advantage received a reply where a person working individually and collectively, depending on the needs will be the best candidate for the ranks of obtaining $63.1 \%$ positive responses.On the other hand a person prefers teamwork received $35.9 \%$. With an individualist only $1 \%$ ie. One miner declared himself to work. This can be seen as a deviation because the work is the host team, cure one person, ie. Patrol makes decisions.

Table 5

The results answer to question 5

\begin{tabular}{lcc}
\hline \multicolumn{1}{c}{ Cooperation in a team } & \multicolumn{2}{c}{ Sum } \\
\cline { 2 - 3 } & number & $\%$ \\
a. The person prefers teamwork & 37 & 35.9 \\
b. The person prefers individual work & 1 & 1.0 \\
$\begin{array}{l}\text { c. A person working individually and } \\
\text { collectively, depending on the needs }\end{array}$ & 65 & 63.1 \\
\hline
\end{tabular}

Attitude to work was another area of research (Table 6). As many as $79.6 \%$ responders chose a person to the ranks, which is characterized by a rational approach to their work. While $4.9 \%$ would choose a person to the ranks of engaging emotionally in the work performed.

Motivation to work contained in Table 7 shows that $85.4 \%$ treat the work as a service and work at the same time, $11.7 \%$ of the professional work and service to others $2.9 \%$.

In Table 8 provides answers about physical fitness. $66.0 \%$ declared that the ranks of most assume rescuer its 
efficiency is based on the systematic cultivation of amateur sport, while $21.4 \%$ of those who base their performance on a periodic practicing sport and recreation. Each lifeguard has a good level of fitness because it must undergo exercise testing during exercise.

Table 6

The results answer to question 6

\begin{tabular}{lcc}
\hline \multicolumn{1}{c}{ Attitude to work } & \multicolumn{2}{c}{ Sum } \\
\cline { 2 - 3 } & number & $\%$ \\
$\begin{array}{l}\text { a. A person takes up reasonably } \\
\text { to work }\end{array}$ & 82 & 79.6 \\
$\begin{array}{l}\text { b. A person engaging emotionally in } \\
\text { the work performed }\end{array}$ & 5 & 14.9 \\
$\begin{array}{l}\text { c. A person engaging emotionally in } \\
\text { the work performed }\end{array}$ & 16 & 15.5 \\
\hline
\end{tabular}

Table 7
The results answer to question 7

\begin{tabular}{lcc}
\hline \multicolumn{1}{c}{ Motivation to work } & \multicolumn{2}{c}{ Sum } \\
\cline { 2 - 3 } & number & $\%$ \\
a. Rescue mining is a professional work & 12 & 11.7 \\
b. Mining is a rescue service to others & 3 & 2.9 \\
$\begin{array}{l}\text { c. Mining is a rescue service and work } \\
\text { at the same time }\end{array}$ & 88 & 85.4 \\
\hline
\end{tabular}

Table 8

The results answer to question 8

\begin{tabular}{lcc}
\hline \multicolumn{1}{c}{ Physical fitness } & \multicolumn{2}{c}{ Sum } \\
\cline { 2 - 3 } & number & $\%$ \\
$\begin{array}{l}\text { a. The efficiency based on periodic } \\
\text { practicing sport and recreation }\end{array}$ & 22 & 21.4 \\
$\begin{array}{l}\text { b. The efficiency is based on the cul- } \\
\text { tivation of competitive sports in the }\end{array}$ & 13 & 12.6 \\
past & & \\
$\begin{array}{l}\text { c. Efficiency is based on the systematic } \\
\text { cultivation of amateur sport }\end{array}$ & 68 & 66.0 \\
\hline
\end{tabular}

Table 9 was dedicated area on the overall performance. $64.1 \%$ declared that rescuers working with him rescuer its performance should be based on the systematic practicing amateur sport. In contrast, $28.1 \%$ for practicing sport and recreation.

Table 9

The results answer to question 9

\section{Overall performance}

a. The performance of based on the systematic practicing amateur sport b. The performance of based on the practicing competitive sports in the past

c. The performance of based on periodic practicing sport and recreation

\begin{tabular}{cc}
\multicolumn{2}{c}{ Sum } \\
\hline number & $\%$ \\
66 & 64.1 \\
8 & 7.8 \\
29 & 28.1 \\
\hline
\end{tabular}

Table 10 contains answers with which the rescuer when it comes to growth of respondents would like to work. Equally, ie. $49.5 \%$ declared for high and medium, only one miner would like to work with low. During the action, the rescuers perform physical labor person higher associated with a person stronger.

Table 11 contains the results in terms of weight potential rescuer in the team. Rescuers declared that the average weight is the weight of the optimum $69.9 \%$. Definitely pre- fer the rescuer with a higher weight $20.4 \%$ lower than $9.7 \%$. Also, this will affect the strength of the rescuer.

Table 10

The results answer to question 10

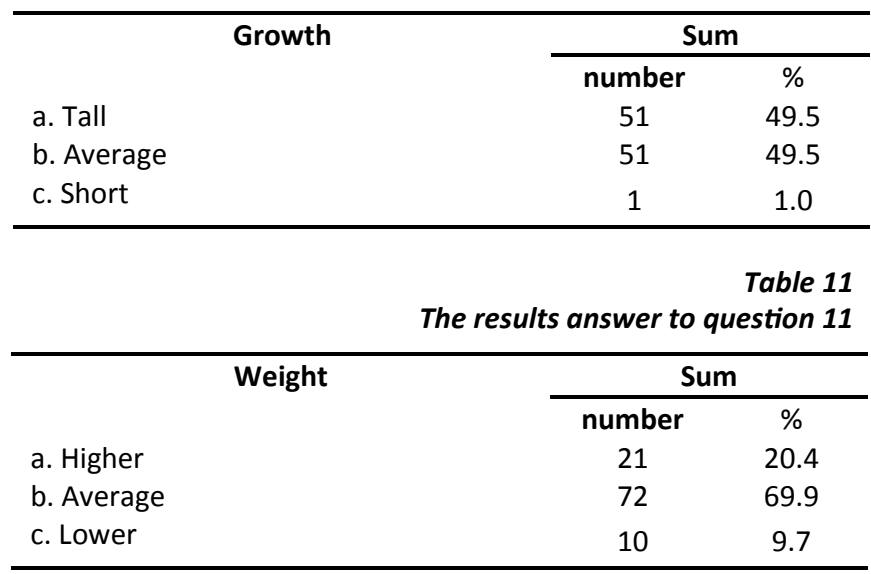

Silhouette sports model as a lifeguard, they want to have the host was $54.4 \%, 31.1$ slim. While massive rescue only 15 (14.5\%) chose this response (Table 12).

Table 12

The results answer to question 12

\begin{tabular}{lcc}
\hline & Silhouette & \multicolumn{2}{c}{ Sum } \\
\cline { 2 - 3 } & number & $\%$ \\
a. Slim & 32 & 31.1 \\
b. Sports & 56 & 54.4 \\
c. Massive & 15 & 14.5 \\
\hline
\end{tabular}

Table 13 shows the results on a lifeguard on BMI, which is to be composed of host up $87.4 \%$ rescuers want to have in your host rescuer with normal BMI. And with increased $10.7 \%$, which accounted for 11 rescuers from the whole research group.

Table 13

The results answer to question 13

\begin{tabular}{lcc} 
& BMI index & \multicolumn{2}{c}{ Sum } \\
\cline { 2 - 3 } & number & $\%$ \\
a. Reduced & 2 & 1.9 \\
b. Normal & 90 & 87.4 \\
c. Elevated & 11 & 10.7 \\
\hline
\end{tabular}

Table 14 refers to the age range of potential rescuer belonging to the ranks. The largest number of rescuers, 33\% chose the rescuer in the range of 31-35 years. You will notice that this is not the youngest or the oldest lifeguard. In second place were the lifeguards over 40 years.

Table 14

The results answer to question 14

\begin{tabular}{lcc}
\hline \multicolumn{1}{c}{ Age } & \multicolumn{2}{c}{ Sum } \\
\cline { 2 - 3 } & number & $\%$ \\
a. Up to 25 years & 7 & 6.8 \\
b. From 26 to 30 years & 21 & 20.4 \\
c. From 31 to 35 years & 34 & 33.0 \\
d. From 36 to 40 years & 13 & 12.6 \\
e. Over 40 years & 28 & 27.2 \\
\hline
\end{tabular}

Table 15 were analyzed recruitment of lifeguards to patrol analyzing seniority in the rescue. Most declarations was in the range from 6 to 10 years of service in the rescue. 
Table 15

The results answer to question 15

\begin{tabular}{lcc}
\hline \multicolumn{1}{c}{ Work experience } & \multicolumn{2}{c}{ Sum } \\
\cline { 2 - 3 } in the mining industry & number & $\%$ \\
a. Up to 5 years & 16 & 15.5 \\
b. From 6 to 10 years & 48 & 46.6 \\
c. From 11 to 15 years & 14 & 13.6 \\
d. From 16 to 20 years & 4 & 3.9 \\
e. Above 20 years & 21 & 20.4 \\
\hline
\end{tabular}

Subsequent compartments is a period of over 20 years, or experienced rescuers.

Seniority as a rescue (Table 16), most often to the ranks of the group would be adopted in the range of up to 5 years constituting $41.7 \%$. Second place was the range from 6 to 10 years, and the smallest group representing 3.9 in the range of $16-20$ years.

Table 16

The results answer to question 16

\begin{tabular}{lcc}
\hline \multicolumn{1}{c}{ Seniority as a rescue } & \multicolumn{2}{c}{ Sum } \\
\cline { 2 - 3 } & number & $\%$ \\
a. Up to 5 years & 43 & 41.7 \\
b. From 6 to 10 years & 38 & 36.9 \\
c. From 11 to 15 years & 13 & 12.6 \\
d. From 16 to 20 years & 4 & 3.9 \\
e. Above 20 years & 5 & 4.9 \\
\hline
\end{tabular}

\section{SUMMARY AND CONCLUSIONS}

1. The study of exercise in the chamber can be concluded that during the simulated action (during exercise) rescuers having more experience defeat excavation smoky in less time than rescuers with less experience.

2. Host consisting of mine rescuers, who have a first degree of obesity by BMI, is also a host of high-speed, in excavations smoky and not smoky.

3. If you would need to create the host of "rapid response" in its composition should find lifeguards displaying the characteristics selected in the survey.

4. The conducted questionnaires, which aimed at identifying the respondent, what attributes should be characterized by a lifeguard, who would work with him in the host - more than $50 \%$ of the respondents granted the following responses:

- the person does not show risk appetite or risk aversion,

- the person does not show an increased nervousness or indifference, optimist,

- a person who is a leader and collaborator depending on the needs,

- person working individually and collectively, depending on the needs,

- most rational person to do the job.

5. People who would like to see the lifeguards in their host should be characterized as:

- exercise capacity based on the systematic practicing amateur sport,

- growth of high and medium.

- average weight,

- athletic silhouette,

- normal BMI.

6. The study shows that most rescuers have accepted the ranks of his rescuer with age range from 26 to 30 years of age having the greatest seniority in the mi- ning industry, however, the optimal length of service in the rescue, according to respondents, is up to 5 years and 610 years.

7. Rescuers participating in the survey at $85.4 \%$ declared that Mine Rescue is a service and work at the same time. Such a response can be regarded as a professional approach to their profession.

\section{REFERENCES}

[1] B. Ćwięk. „Ryzyko w ratownictwie górniczym”, in Bezpieczeństwo Pracy $i$ Ochrona Środowiska w Górnictwie, no. 5, 1998, pp. 30-35.

[2] J. Drenda. „Zmiany parametrów fizjologicznych człowieka pracującego w gorących środowiskach - wyniki pomiarów eksperymentalnych", in Zeszyty Naukowe Politechniki Ślq̨skiej (s. Górnictwo), tom 261, 2004, pp. 385-396.

[3] A.D. Gillies, H.W. Wu and A.M. Wala. „Australian mine emergency exercises aided by fire simulation", in $\mathrm{Ar}$ chives Mining Sciences, vol. 50(1), 2005, pp. 17-47.

[4] Z. Goldstein, B. Bagiński and J. Michalski. „Bezpieczny czas pracy ratowników górniczych, pracujących w trudnych warunkach mikroklimatu" in Zeszyty Naukowe Politechniki Ślqakiej (s. Górnictwo), tom 253, 2002, pp. 51-60.

[5] A. Grodzicka, A. Chłopek and J. Szlązak. Specjalistyczne pogotowia w ratownictwie górniczym, Gliwice: Wydawnictwo Politechniki Śląskiej, 2015.

[6] Z. Knapik et al. „Wydatek energetyczny górnikówratowników w czasie symulowanej akcji ratowniczej", in Rudy i Metale Nieżelazne, vol. 36(8), 1991, pp. 279281.

[7] J. Martyka and K. Lebecki. „Safety culture in high-risk industries", in International Journal of Occupational Safety and Ergonomics, vol. 20(4), 2014, pp. 561-572.

[8] J. Martyka. „Kształtowanie bezpiecznych zachowań i uwarunkowania ich podejmowania", in Bezpieczeństwo pracy w kopalniach węgla kamiennego. Górnictwo $i$ środowisko, tom 1, W. Konopko, Katowice: Główny Instytut Górnictwa, 2013, pp. 317-352.

[9] J. Martyka. „Rola zarządzania potencjałem społecznym i kierowania zachowaniami organizacyjnymi w kreowaniu kultury bezpieczeństwa załóg górniczych", in Bezpieczeństwo Pracy i Ochrona Środowiska w Górnictwie, no. 8, 1997, pp. 54-59.

[10] J. Martyka. „Stan kultury bezpieczeństwa jako wyznacznik poziomu bezpieczeństwa zachowań pracowników KWK", in Bezpieczeństwo Pracy i Ochrona Środowiska w Górnictwie, no. 7, 1997, pp. 21-25.

[11] Z. Niczyporuk. Podstawy zarzqdzania bezpieczeństwem w czasie akcji ratowniczej, Katowice: Główny Instytut Górnictwa, 2000.

[12] A. Plata. „Obciążenie cieplne ratowników górniczych w czasie akcji ratowniczej prowadzonej w trudnych warunkach cieplnych", in Cuprum: Czasopismo naukowotechniczne górnictwa rud, no. 11, 1999, pp. 83-91.

[13] J. Sobala and P. Rozmus. System zarzqdzania bezpieczeństwem pracy w zakładach górniczych, Katowice: Główny Instytut Górnictwa, 1997.

[14] J. Sułkowski. „Ryzyko w akcjach ratowniczych prowadzonych w polach metanowych po powstaniu wybuchów lub pożarów", in Bezpieczeństwo Pracy i Ochrona Środowiska w Górnictwie, no. 3, 2008, pp. 3-11.

[15] J. Szlązak et al. „Ratownictwo górnicze. Część 6. Analiza czasu przejścia zastępów ratowniczych w aspekcie 
parametrów fizjologicznych i doświadczenia zawodowego ratowników górniczych. Podsumowanie", in Wiadomości Górnicze, vol. 65(11), 2014, pp. 611-614.

[16] J. Szlązak et al. „Ratownictwo górnicze. Część 2. Wydolność organizmu i czas przejścia ratowników podczas badań w komorze ćwiczeń według wskaźnika BMI", in Wiadomości Górnicze, vol. 65(6), 2014, pp. 361-368.

[17] J. Szlązak et al. „Ratownictwo górnicze. Część 4. Czas przejścia przez komorę ćwiczeń zespołów ratowniczych z uwzględnieniem wzrostu ratowników", in Wiadomości Górnicze, vol. 65(9), 2014, pp. 496-503.

[18] J. Szlązak et al. „Ratownictwo górnicze. Część 3. Analiza wieku i doświadczenia zawodowego ratowników w aspekcie czasu przejścia ich zastępów", in Wiadomości Górnicze, vol. 65(7-8), 2014, pp. 423-430.

[19] J. Szlązak et al. „Ratownictwo górnicze. Część 1. Etapy badań zastępów ratowniczych w wyrobisku ćwiczebnym", in Wiadomości Górnicze, vol. 65(5), 2014, pp. 301-304.
[20] J. Szlązak et al. „Ratownictwo górnicze. Część 5. Wpływ częstości akcji serca ratowników na czas ich przejścia przez komorę ćwiczeń", in Wiadomości Górnicze, vol. 65(10), 2014, pp. 557-564.

[21] J. Szlązak and N. Szlązak. Ratownictwo górnicze, Kraków: Wydawnictwo Akademii Górniczo-Hutniczej, 2010.

[22] K. Tausz and J. Martyka. „Kształtowanie probezpiecznych zachowań górników", in Strategia poprawy bezpieczeństwa pracy w kopalniach węgla kamiennego, W. Konopko, Katowice: Główny Instytut Górnictwa, 2001, pp. 331-414.

[23] Ustawa z dnia 9 czerwca 2011 r. - Prawo geologiczne i górnicze, Dz.U. 2015 r. poz. 196, 2015.

[24] Rozporzqdzenie Ministra Gospodarki z dnia 12 czerwca 2002 r. w sprawie ratownictwa górniczego, Dz.U. 2002 r. nr 94 poz. 838 z późn. zm, 2002.

dr inż. Aneta Grodzicka, prof. dr hab. inż. Jan Szlązak

Silesian University of Technology,

Faculty of Mining and Geology, Institute of Mining

ul. Akademicka 2a, 44-100 Gliwice, POLAND

e-mail: aneta.grodzicka@polsı.pl

jan.szlazak@polsı.pl 